\title{
SEISMIC OBSERVATIONS WITH BROADBAND INSTRUMENTS AT SANTORINI VOLCANO
}

\author{
Kolaitis A. ${ }^{1}$, Papadimiriou P. ${ }^{1}$, Kassaras I. ${ }^{1}$, and Makropoulos K. ${ }^{1}$
}

\begin{abstract}
${ }^{1}$ National and Kapodistrian University of Athens, Faculty of Geology and Geoenvironment, Department of Geophysics-Geothermics,, Panepistimioupolis, Zografou, Athens 15784, akolaitis@geol.uoa.gr,ppapadim@geol.uoa.gr,kassaras@geol.uoa.gr,kmacrop@geol.uoa.gr
\end{abstract}

\begin{abstract}
Two arrays equipped with broadband sensors were installed for a period of 10 months, in order to study the seismic activity in the area of Santorini (Thira) volcano. During these periods, about 330 earthquakes were recorded and located within a radius of $50 \mathrm{~km}$ from the center of the caldera. An iterative damped traveltime inversion procedure yielded a local 1-D P-wave velocity model and improved locations with an accuracy better than $5 \mathrm{Km}$ in both horizontal and vertical components for 135 earthquakes. Those are mainly distributed within a depth range 5-18 Km, in the vicinity of the submarine Kolumbo Reef (NE of Santorini Island). Signal analysis of the recorded volcanic earthquakes including typical Fourier transformations and several operations in the time-frequency domain, allowed their dominant frequency determination and their classification into three groups based on waveform appearance and frequency content: (1) highfrequency events; (2) low-frequency events; and (3) volcanic tremor. Frequencytime analysis of tremor, detected at three stations, revealed two kinds of harmonic tremor with one sharp peak, at 3-5 $\mathrm{Hz}$ and 8.5-10 Hz.
\end{abstract}

Key words: Santorini, volcanic earthquakes, spectral analysis.

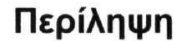

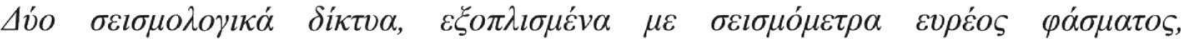

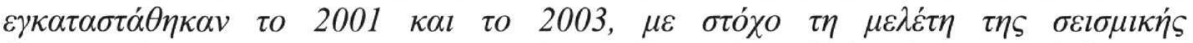

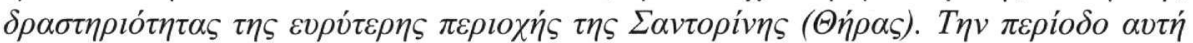

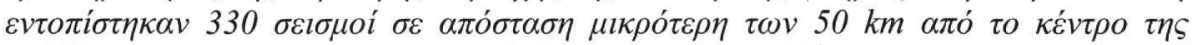

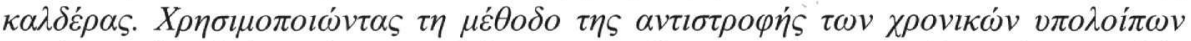

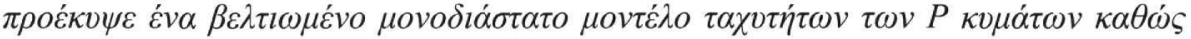

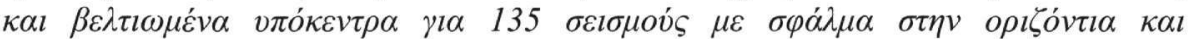

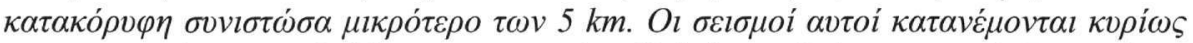

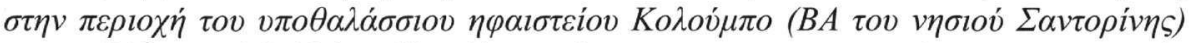

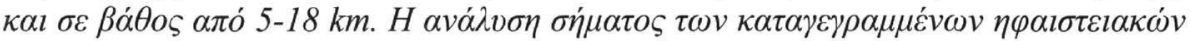

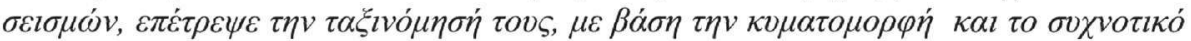

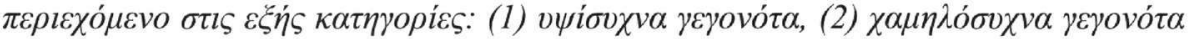

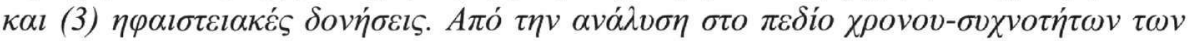

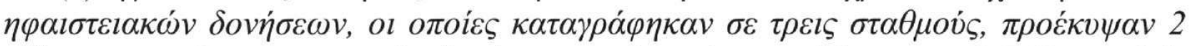

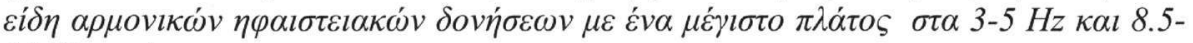

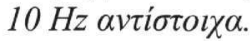

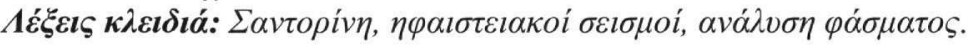




\section{Introduction}

The Hellenic arc is one of the dominant tectonic features within the Aegean region. It consists of an outer sedimentary arc in the south and an inner volcanic arc in the north with Quaternary volcanoes. Santorini is the most active field within the South Aegean volcanic arc, activated for at least 7 times during the last 500 years (Papazachos 1989, Fytikas et al. 1990). The main tectonic feature in the area of Santorini is the Amorgos fault with a NE-SW direction, which generated a $\mathrm{M}=7.5$ earthquake in 1956 (Shirokova 1972, Papazachos et al. 2001, Pavlides and Valkaniotis 2003). Another tectonic feature in the Santorini area is a graben located north of the island, with approximately ENE-WSW direction (Perissoratis 1996). Santorini is a group of five islands, namely Santorini, Therasia, Aspronisi, Palea Kammeni and Nea Kammeni. The most characteristic type of activity over the last $200 \mathrm{Ka}$ has been the cyclic construction of shield volcanoes interrupted by large eruptive events like the Minoan eruption (Druitt et al. 1989, 1999).

It has been well established that volcanic activity, seismicity and tectonics in a region are directly related to each other. However, although the correlation between hydrothermal activity and earthquakes has been pointed out since almost 20 years, regions of intense hydrothermal activity, such as volcanic arcs or middle-ocean ridges, have not been adequately investigated. There are currently strong evidences that, hydrothermal activity in the volcanic arc of the Aegean, in combination with magmatism and existing geotectonic features, induce seismic activity, which in some cases is not negligible (Papanikolaou et al. 1993, Makropoulos et al. 1998). It is likely that the region of the Aegean volcanic arc exhibits three types of seismic phenomena, attributed to different origin: tectonic, magmatic and hydrothermal. The systematic study and monitoring of geochemical, hydrothermal, seismic and tectonic processes associated with variations of the volcanic and especially of the hydrothermal activity in volcanic regions, could yield important information about the probability of large earthquakes occurrence. In this paper, we present results of the analysis of seismic data recorded by two local temporary broadband seismological networks installed in the area of Santorini and attempt an approach to their implication within its volcanic environment.

\section{Seismic monitoring of the Santorini volcano}

\subsection{Local seismological arrays}

Within the framework of a project on volcanic hazard assessment funded by the Greek Earthquake Planning and Protection Organization (EPPO), in the summer of 2001, the SANNET-2001 (SANtorini NETwork) was installed. SANNET-2001 consisted of 6 stations, three of them equipped with broadband 3-component CMG-40T $(0.03-50 \mathrm{~Hz})$ sensors and three with 3component CMG-40T (1-50 Hz) sensors. Data loggers were REFTEK-72A 24-bit type, recording continuously at a rate of 200 samples per second. GMT absolute timing was provided by GPS receivers. SANNET-2001 was installed in June 2001 and remained in operation until November 2001.

In March 2003 a new seismological network the SANNET-2003 was installed and remained in operation until September 2003. SANNET-2003 consisted of 5 REFTEK-132 instruments equipped with 3-component CMG-40T sensors. Four of them were equipped with broadband 3component CMG-40T $(0.03-50 \mathrm{~Hz})$ sensors and one with 3-component CMG-40T $(1-50 \mathrm{~Hz})$ sensor. The advantage of broadband sensors is the possibility to record low frequency (less than 1 $\mathrm{Hz}$ ) signals that might be related with magmatic activity or other volcanic processes (Jousset et al. 2003). Three of the stations were installed in Santorini (Swin, Inpi and Oiax), one in Nea Kameni Island (Nkam) and one in Thirasia Island (Elik). Swin station was removed two times (Buta, Oter) because of local noisy conditions. Description of the two seismological arrays (SANNET-2001, SANNET-2003) is given in Table 1. Their geographical distribution is shown in Figure 1. 
Concerning the raw data manipulation, the continuous recordings from REFTEK hard drives were stored into DDS tapes. Then, those were stored in a PC hard drive where they were archived. As a result of this procedure two datasets were produced for the first (2001) and the second experiment (2003). By further processing the two datasets, we obtained a unified database including only signals that could be related to volcanic activity.

Table 1 - Description of temporary Seismological arrays

\begin{tabular}{|c|c|c|c|c|c|c|}
\hline \multicolumn{7}{|c|}{ SANNET - 2001} \\
\hline Station & Location & Latitude & Longitude & Alt. (m) & Resp. (sec) & Operation \\
\hline Anaf & Anafi Isl. & 36.357 & 25.773 & 260 & $0.02-1$ & $22 / 06-10 / 11$ \\
\hline Fini & Santorini & 36.463 & 25.394 & 140 & $0.02-33$ & $23 / 06-18 / 10$ \\
\hline Kame & N. Kameni & 36.408 & 25.399 & 40 & $0.02-33$ & 20/06-07/11 \\
\hline Kera & Thirasia & 36.417 & 25.348 & 180 & $0.02-1$ & 19/06-15/07 \\
\hline Nios & Ios & 36.720 & 25.280 & 54 & $0.02-1$ & $21 / 06-02 / 11$ \\
\hline Pili & Santorini & 36.370 & 25.459 & 540 & $0.02-33$ & $19 / 06-02 / 11$ \\
\hline \multicolumn{7}{|c|}{ SANNET - 2003} \\
\hline Station & Location & Latitude & Longitude & Alt. (m) & Resp. (sec) & Operation \\
\hline Oiax & Santorini & 36.4661 & 25.3799 & 136 & $0.02-33$ & 29/03-03/09 \\
\hline Nkam & N. Kameni & 36.3996 & 25.4046 & 43 & $0.02-33$ & 28/03-03/09 \\
\hline Elik & Thirasia & 36.4339 & 25.3430 & 205 & $0.02-33$ & 29/03-04/09 \\
\hline Inpi & Santorini & 36.4215 & 25.4303 & 289 & $0.02-1$ & 27/03-02/09 \\
\hline Oter & Santorini & 36.3686 & 25.4639 & 567 & $0.02-33$ & 21/06-02/09 \\
\hline Buta & Santorini & 36.3706 & 25.4251 & 180 & $0.02-33$ & $24 / 05-21 / 06$ \\
\hline Swin & Santorini & 36.3876 & 25.4364 & 330 & $0.02-33$ & $27 / 03-24 / 05$ \\
\hline
\end{tabular}

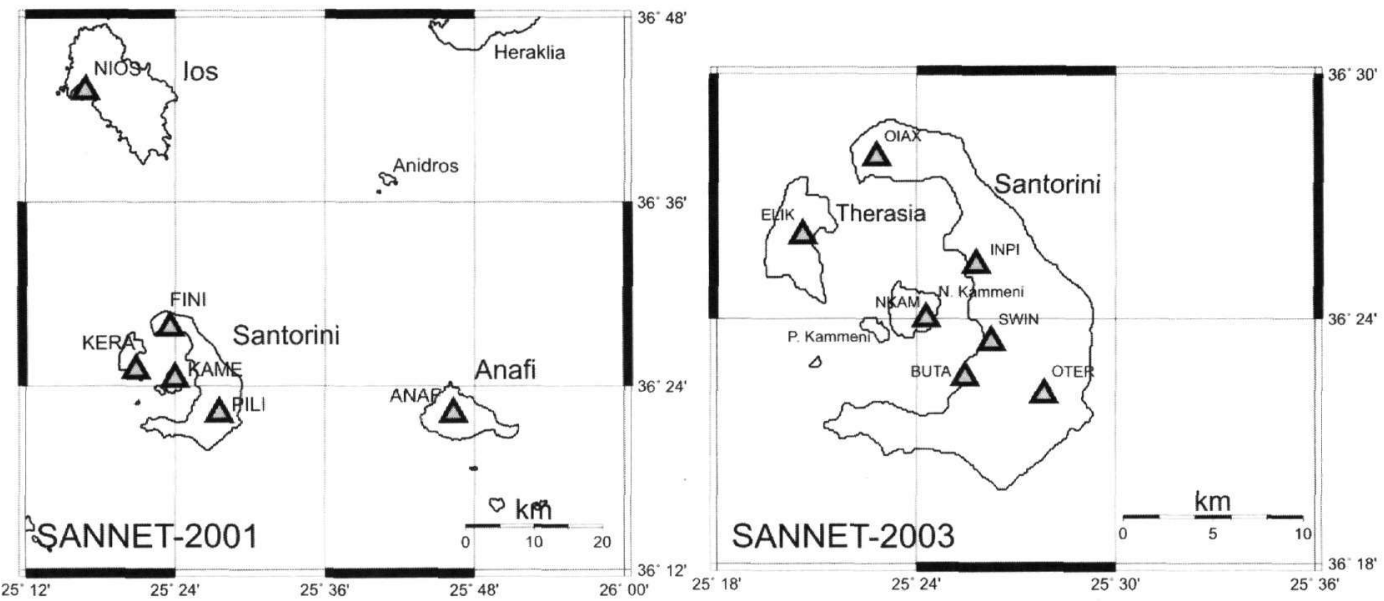

Figure 1 - Geographical distribution of SANNET-2001 and SANNET-2003 stations

\subsection{Hypocentral locations}

Waveforms from SANNET-2001 and SANNET-2003 were analyzed manually by measuring arrival times at events with a good signal-to-noise ratio. Weights were assigned to each picked arrival time, using 0 as best and 4 as worst quality. HYPO71 algorithm (Lee and Lahr 1975) was used in order to locate the recorded events. A crustal velocity model proposed by Delibassis et al. 
1989, 1993, was employed as the initial earth model. Given the foci scattering especially over a significant depth range due to the simplified earth model used, we considered necessary the determination of a new velocity model for the volcano area in order to improve the accuracy of the hypocentral locations. For this purpose, considering a subset of well located local earthquakes, we used the mean RMS minimization technique (Crosson 1976) in order to obtain a new velocity model (Table 2, columns 3 and 4). For the application of this method, hypocenters were selected on the basis of the minimum epicentral distance (DMIN $<30 \mathrm{~km}$ ), RMS $<0.4 \mathrm{sec}, \mathrm{ERX}<5 \mathrm{~km}$ and available number of seismic phases $\mathrm{NbPH}>5$. The velocity model derived from this technique was used as input in the VELEST algorithm (Kissling et al.1994, 1995). VELEST simultaneously inverts for 1-D velocities, hypocenter locations and station delays. The forward problem is solved by ray-tracing, computing direct, refracted and reflected rays passing through the 1-D model. The inverse problem is solved by using a standard iterative damped least-squares method. The result was an improved velocity model (Table 2, columns 5 and 6), which yielded reduced traveltime residuals and hypocentral uncertainties by about $20 \%$ in both horizontal and vertical components.

Table 2 - Initial velocity model and the derived velocity models

Delibassis. et al., 1989, 1993

$\mathrm{Vp}(\mathrm{km} / \mathrm{sec})$

4.0

6.0

6.6

7.7

8.1
Depth (km)

0.0

1.1

24.0

32.0

40.0
P-MINRMS

$\mathrm{Vp}(\mathrm{km} / \mathrm{sec}) \quad$ Depth $(\mathrm{km})$

4.2

5.3

5.7

6.3

6.6

7.0
0.0

1.1

4.2

11.8

17.8

22.0
P-VELEST

$\begin{array}{cc}\mathrm{Vp}(\mathrm{km} / \mathrm{sec}) & \text { Depth }(\mathrm{km}) \\ 4.20 & 0.0 \\ 5.33 & 1.1 \\ 5.71 & 4.2 \\ 6.35 & 11.8 \\ 6.60 & 17.8 \\ 7.00 & 22.0\end{array}$

\subsection{Distribution of earthquake activity in Santorini area}

Using the new velocity model (P-VELEST) derived from the iterative method of Kissling et al. 1994,1995 , the focal parameters of the recorded events were estimated. 170 hypocenter locations of microearthquakes with magnitudes $0.9 \leq \mathrm{M} \leq 2.9$ were estimated for the period June-October 2001 and 162 with magnitudes $1.0 \leq \mathrm{M} \leq 4.0$ for the period April-August 2003. The spatial distribution of the located epicenters is shown in Figure 2 for each recording period.

The majority of the events recorded during 2001 (left map of Fig. 2), except for some events located E-SE of Anafi Island, are lineated in an approximately ENE-WSW direction. Similar trending in the area was found for the isolines of Bouguer anomalies (Budetta et al. 1983). Furthermore, reflection profiles show that structural lineaments have an ENE-WSW trend in the eastern part of Aegean volcanic arc (Mascle and Martin 1990). The observed activity could be associated with a main active tectonic feature, the continuation of the Amorgos fault in the area, which has a $\sim \mathrm{N} 60^{\circ} \mathrm{E}$ direction.

Seismic activity during the recording period in 2003 (right map of Fig. 2) appears clustered in the vicinity of the submarine Kolumbo volcano which is situated NE of Santorini. This activity pattern is mainly due to the occurrence of an earthquake swarm in the specific area, with the largest event being $M=4.0$. The best located events ( $R M S<0.25 \mathrm{sec}, \mathrm{ERH}<5 \mathrm{~km}, \mathrm{ERZ}<5 \mathrm{~km}$ ) during the two recording periods are shown in figure 3. Most of them are located beneath the Kolumbo crater. The pattern of the best located seismic activity appears to be lineated in an approximately $\mathrm{N} 60^{\circ} \mathrm{E}$ direction, similar to the trend of Amorgos fault.

The depth distribution of the best located foci is shown in the cross-sections of Figure 3 . The seismic activity during the two recording periods reveals a depth distribution mainly between 5 and $25 \mathrm{~km}$. The deepest foci are located NE of Santorini, beneath Kolumbo volcano and beneath the Santorini caldera. From the cross section in NE-SW direction (left in Fig. 3) a fault plane 
dipping approximately $50^{\circ} \mathrm{SE}$ could be defined. The cross section in W-E direction (right in Fig. 3) shows that the seismogenic field is extended to a larger depth toward the east. The distribution of foci beneath the caldera shows that the magmatic chamber and the main magmatic vent are located at depths 1-20 km. Unfortunately, due to the networks geometry it was not possible to estimate focal mechanisms. Considering the existent structural geometry (Shirokova 1972) and the extensional strain field in the Aegean area (McKenzie 1978, Papazachos et al. 1991), the seismic deformation observed in the area could be attributed to normal faulting.
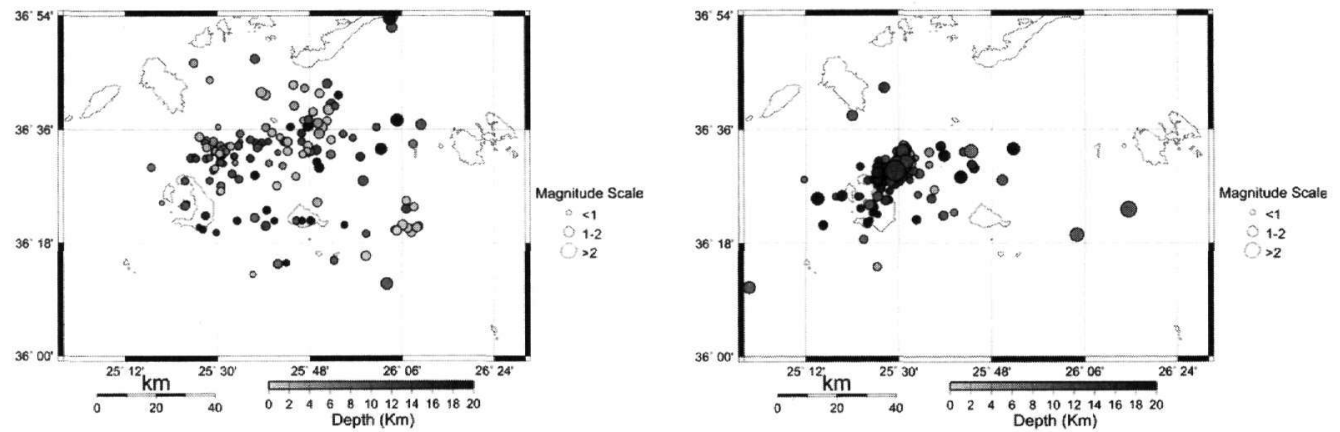

Figure 2 - Spatial distribution of epicenters: Left for the period June-October 2001 and right March-August 2003
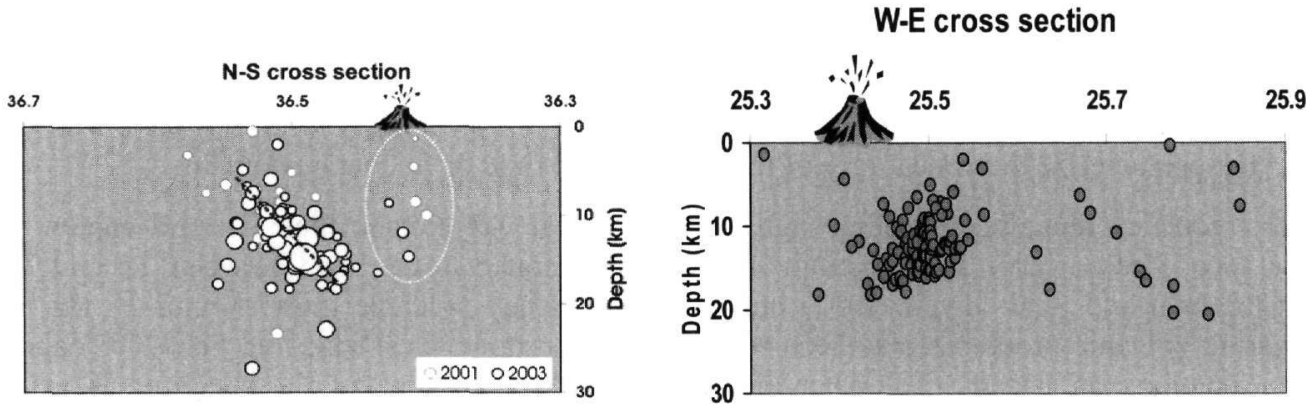

Figure 3 - Cross-sections in N-S (left) and in W-E (right) direction

The seismogenic field in Santorini area extends in larger depth than in other seismically active areas in Greece, where the depth range of shallow earthquakes is $0-15 \mathrm{~km}$. It is remarkable that foci beneath the caldera appear in large depth, down to $20 \mathrm{~km}$. Considering recent studies on the Aegean deep velocity structure (Karagianni et al. 2001, Kassaras 2002), the lithosphere depth does not exceed $22-23 \mathrm{~km}$ in Santorini area. The above imply that seismic strain in Santorini area is distributed over the whole lithosphere. Such a thin and weak (fragmented) lithosphere is presumably the effect of magma convection and hydrothermal fluids circulation due to the subduction processes which formed the active Hellenic volcanic arc. These results suggest that the observed seismic deformation is originated in domains with complex characteristics, which constitute the discrimination of volcanic earthquakes quite difficult.

\subsection{Description of seismic signals}

The first and most popular classification of volcanic earthquakes was done by Minakami (1960, 1974) which is based not in the source process but in the waveform shape and amplitude spectrum. According to this classification we have the following kinds of volcanoseismic phenomena:

High frequency events (A-type volcanic earthquakes). They occur in volcano base and in a depth about 1-20 km. The waveform is characterized by a high frequency, impulsive P-wave onset with a coda that decays almost exponentially with time. Most energy is concentrated in the frequency 
range $5-15 \mathrm{~Hz}$. These types of earthquakes were produced by shear fracture or slip on faults and they are different from tectonic events only in their pattern of occurrence, which, at volcanoes, are typically in swarms, rather than mainshock-aftershock sequences (McNutt 2000).

Low frequency events (B-type volcanic earthquakes). Their depth is less than A-type volcanic earthquakes and they usually occur near and around the volcano. The waveform is characterized by an emergent P-wave onset and lack of S phases and the coda decays slowly with time. The energy in the spectrum is widespread in the frequency range 1-5 Hz (Kawakatsu et al. 2000). Their associated source models range from an opening and resonating crack when the magma is ascending towards the surface (Chouet 1996a) to existence of pressure transients within the fluidgas mixture causing resonance phenomena within the magma itself (Seidl et al. 1981). Both models are able to explain a large part of the observed features in the spectral domain.

Explosion quakes. Explosion quakes usually accompany explosive eruptions and many are characterized by the presence of an air-shock phase on the seismograms which is caused by the sonic boost during an explosion, when the expanding gas is accelerated at the vent exit. The source which causes this explosion is not yet clear. Some low frequency events show the same frequency-time behavior as the explosion quakes but lack an air phase (McNutt 1986, Neuberg et al. 2000). This might reflect a common source mechanism of deeper situated low frequency events and shallow produced explosion quakes.

Volcanic tremor. Volcanic tremor is a quasi-continuous to continuous signal of duration from minutes to days or longer. In many classification schemes (Minakami 1960, Latter 1979) the term volcanic tremor is being used in order to describe tremor signals of varying amplitude and duration. Other terms (harmonic, monochromatic, banded, spasmodic, tremor storm) and modifiers (Schlidwein et al. 1995, Hurst 1992, McNutt 1996, Seidl et al. 1990) have also been used, that characterize the appearance of the signal in the time or frequency domain.

In the frequency domain the tremor signal show a great variation in their spectral content and appearance. The power in the spectrum is often concentrated in the band between $0.5 \mathrm{and} 7 \mathrm{~Hz}$ (Konstantinou and Schlindwein 2002) but higher frequency volcanic tremors until $15 \mathrm{~Hz}$ from submarine volcanic processes, has been recorded by hydrophones (Dziac and Fox 2002) and by seismic stations on islands (Talandier and Okal 1996). The shape of the spectrum is usually dominated by one or more sharp peaks that represent either a fundamental frequency and its harmonics or a random distribution of peaks (Sherburn et al. 1998).

The models suggested as possible sources of tremors can be grouped as follows: (a) fluid-flowinduced oscillations of conduits transporting magmatic fluids (Chouet and Julian 1985) (b) excitation and resonance of fluid-filled cracks (Chouet 1986, Chouet 1988) (c) bubble growth or collapse due to hydrothermal boiling of groundwater (Leet 1988) (d) a variety of models involving the oscillations of magma bodies with different geometries (Chouet 1985).

\subsection{Processing of seismic signals}

In most studies of volcanic tremor the estimation of the frequency content has been one of the primary tools for investigating the nature of the signal. Hence, typical signal analysis was performed in this study, attempting to investigate the characteristics of the recorded events, within a complex volcanic environment. Signal analysis was performed utilizing SAC2000 software (Goldstein et al. 1998). The procedure we followed was a) zero line signal correction, b) linear trend removal, c) application of a symmetric taper, d) bandpass filtering between $0.5-10 \mathrm{~Hz}$ when necessary and e) Fast Fourier Transformation (FFT).

Using the above analysis we concluded that the majority of earthquakes are mainly A-type because they: (1) distribute in depth from 5-18 km, (2) have impulsive P-wave onset and clear Swave arrival, (3) the energy concentrates in the frequency range $2-15 \mathrm{~Hz}$ and (4) the polarity of the first $\mathrm{P}$-wave arrival and the $\mathrm{P} / \mathrm{S}$ amplitude ratio vary azimuthally. 


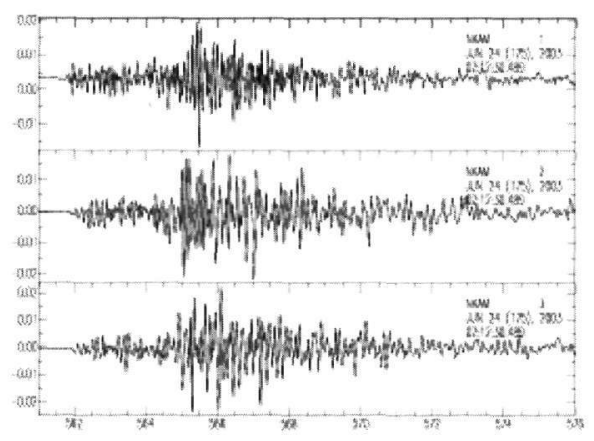

time (sec)

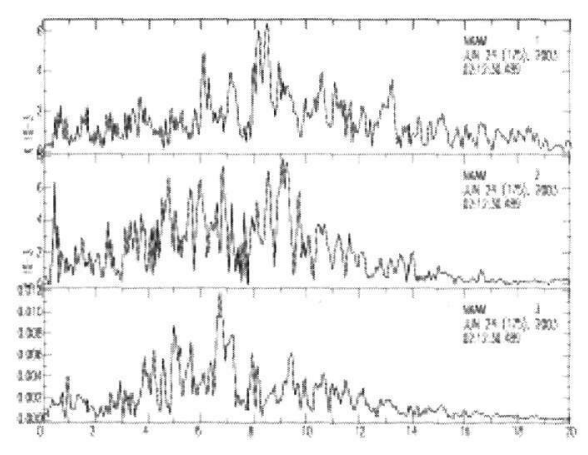

frequency $(\mathrm{Hz})$

\section{Figure 4 - Three component velocity waveforms and amplitude spectra ot a nigh trequency event recorded at Nkam station on 24 of April 2003. 1: vertical component, 2: north-south component, 3: east-west component}

In figure 4 an example of a three component waveform and its amplitude spectra for a high frequency event recorded at Nkam station on April 2003 is shown. We can discriminate clearly the $\mathrm{P}$ - and S-wave arrival in all waveform components and the dominant frequencies in amplitude spectra are distributed in the band between 2 and $12 \mathrm{~Hz}$.

In 2001 we did not detect any low frequency event. However, in 2003 we detected some of them (Fig. 5). From this figure we can easily discriminate all the required B-type characteristics. In the first part of figure 5 a low frequency event recorded at Swin station on 04 of April 2003 is shown. Its waveform is characterized by emergent signal onset, lack of S-wave arrivals and coda decaying slowly with time. Moreover the amplitude spectra differ from that of a high frequency event as the energy is restricted in a narrow frequency band between 1-5 Hz. In the second part of figure 5 another low frequency event which is recorded at Inpi station on 27 of May 2003 is shown. It is characterized by an emergent onset as well as by slowly coda decaying. The spectrum energy is restricted in all components into two narrow frequency bands between $1-2 \mathrm{~Hz}$ and $2.5-4.5 \mathrm{~Hz}$.

Although the estimation of the frequency content of volcanic tremor has been one of the primary tools for investigating the nature of a signal, not any method used for the calculation of the spectrum appears able to cope successfully with a number of characteristics of the signal due to the nature of the employed data. Firstly, tremor can persist for long periods of time resulting in the accumulation of large amounts of data that have to be analyzed. Secondly, it may exhibit strong temporal variations in amplitude or frequency content that should be monitored because of their importance for source modeling and eruption forecasting. Thirdly, the calculated spectrum may include multiple sharp peaks around narrow frequency bands, a case in which a high degree of resolution is required to resolve the individual frequencies.

In order to detect temporal variations in the frequency content and to resolve efficiently possible multiple energy peaks in the signal, a direct comparison of the averaged spectra was performed. Such a comparison between spectra concerning different time periods is feasible only when the amount of data is relatively small and the observed variations are larger than the ambient noise levels. A better way of detecting temporal variations is by incorporating all the variables that are likely to change (time, frequency, and amplitude). This was accomplished by calculating spectrograms, a 2D representation of the variations of spectral amplitude and frequency of the observed signal as time elapses. Using the SAC2000 software, spectrograms were produced for all stations and each component. The spectrograms were calculated for a $0.5 \mathrm{~s}$ window and $50 \%$ overlap using the technique of Goldstein and Minner (1996). 
(a)

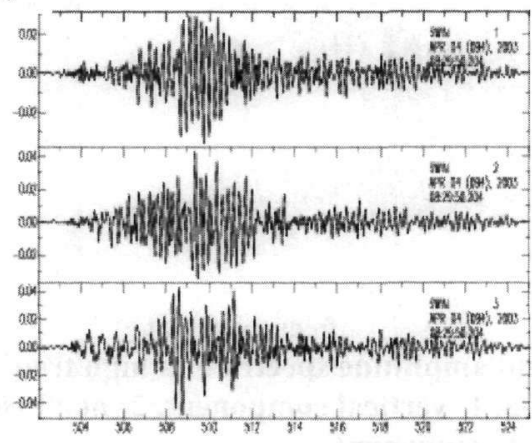

time $(\mathrm{sec})$

(b)

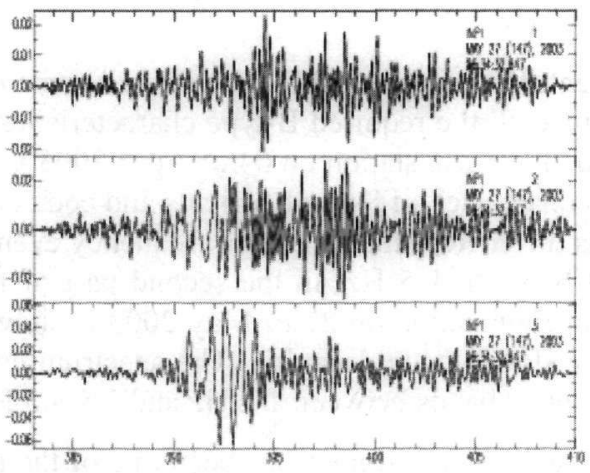

time (sec)

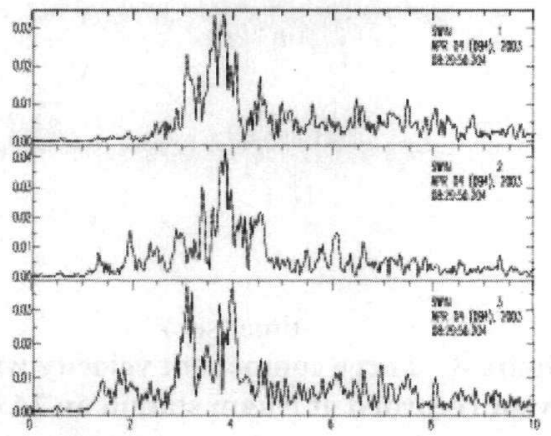

frequency $(\mathrm{Hz})$

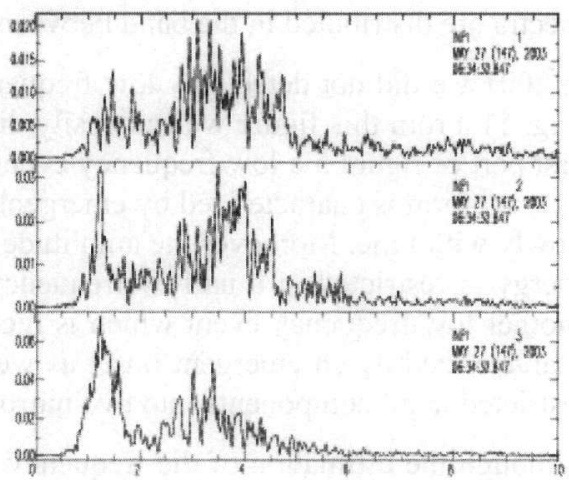

frequency $(\mathrm{Hz})$

Figure 5 - Three component velocity waveforms and its amplitude spectra of two low frequency events recorded (a) 04 of April 2003 at SWIN station and (b) 27 of May 2003 at INPI station. 1: vertical component, 2: north-south component, 3: east-west component

The result of this work was the detection of typical harmonic tremor recorded at Fini, Oiax, Inpi, Swin and Buta stations. The energy in the spectrum is concentrated in the frequency band between $8-10 \mathrm{~Hz}$. The amplitude of the energy is not constant, but varies as time elapses. Moreover, a harmonic tremor characterized by one sharp peak in the frequency band between $3-5 \mathrm{~Hz}$ was recorded at Inpi, Swin and Buta stations. In Figure 6, an example of harmonic tremors is shown. Figure 6a, displays a harmonic tremor recorded on March 29, 2003 at Swin station. The energy of the spectrum is restricted in a narrow band $2-4 \mathrm{~Hz}$. Figure $6 \mathrm{~b}$, displays a harmonic tremor recorded at Inpi station on June 9, 2003. The resulting spectrogram consists of only one sharp peak at $9 \mathrm{~Hz}$ and extends in the frequency band between $8-10 \mathrm{~Hz}$. 

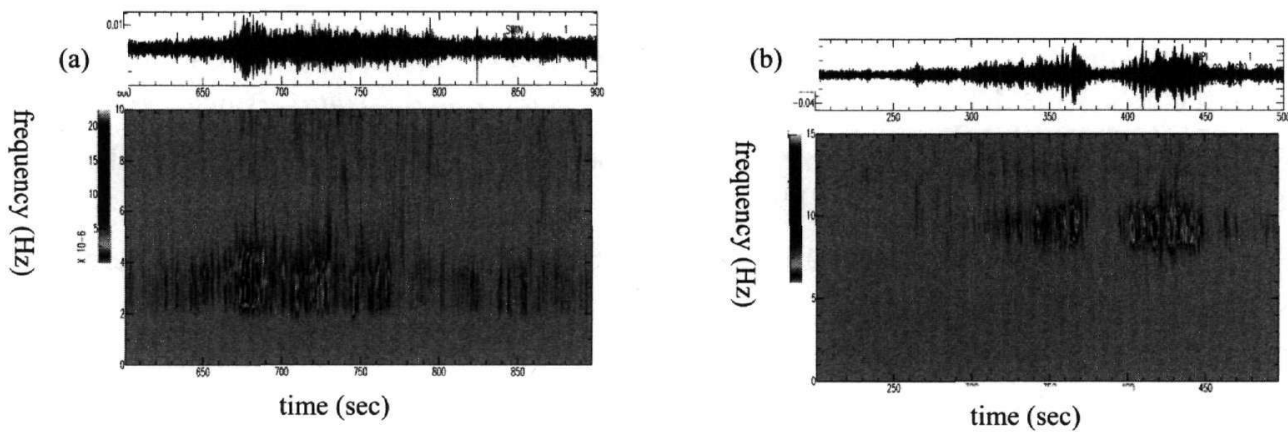

Figure 6 - Vertical component of harmonic tremor recorded at (a) Swin station on March 29, 2003 and (b) Inpi station on June 9, 2003. Dark shades in the spectrograms indicate high energy

\section{Conclusions}

Santorini volcanic field is the most active of the south Aegean volcanic arc. It comprises two of the three active volcanic Aegean centers, these of Kameni and Kolumbo. Investigations on the seismic activity were carried out by the installation of two temporary local seismological networks in 2001 and 2003. The seismic activity during the monitoring periods appears in a low level beneath the caldera and in a high level beneath the Kolumbo Reef. A considerable increase of seismic activity was observed in 2003 in the vicinity of the submarine Kolumbo volcano. This increase is mainly due to the occurrence of a microearthquake swarm in this area, with the largest event being of $M=4.0$. In general, the epicenters are lineated in ENE-WSW direction, in agreement with seismicity recorded at different periods (Papazachos and Panagiotopoulos 1993, Dimitriadis et al. 2005). The pattern of the best located seismic activity appears to be lineated in an approximately $\mathrm{N} 60^{\circ} \mathrm{E}$ direction, similar to the trend of the continuation of Amorgos fault in the area. The dip of this rupture zone was defined $\sim 50^{\circ} \mathrm{SE}$. Considering the existing structural geometry and the extensional strain field in the south Aegean area, the seismic deformation observed in the area should be attributed to normal type of faulting. The seismogenic field in Santorini area extends in larger depth than in other seismically active areas in Greece, crossing the whole lithosphere, which appears thinned in this area. Such a thin and fragmented lithosphere is presumably the effect of magma convection and hydrothermal fluids circulation due to the subduction processes. These results suggest that the observed seismic deformation is originated in domains with complex characteristics, which constitute the discrimination of volcanic earthquakes difficult.

Despite the poor geographical coverage of the recording stations, an appropriate velocity model was estimated, in order to improve the accuracy of the hypocentral locations and to derive a preliminary knowledge about the shallow velocity structure of the Santorini area.

By applying fast Fourier transformations on the recorded earthquakes we attempted to classify them within the frame of a volcano-tectonic environment, based on the shape of spectra and the frequency content. The analysis showed that the majority of the recorded seismic activity was Atype volcanic earthquakes, however, a small amount of B-type events was detected in 2003 . These B-type events were recorded mainly at Swin and Inpi stations. Unfortunately it was not possible to locate any low frequency events due to the poor station coverage and the lack of good signal-tonoise ratio recordings in more than one station. Frequency-time analysis of signals produced at various time periods revealed volcanic tremor in north and central Santorini (Fini, Oiax, Inpi, Swin, Buta stations) with a dominant frequency at $9 \mathrm{~Hz}$. Moreover, harmonic tremor with a dominant frequency at $3.5 \mathrm{~Hz}$ was recorded at Swin and Inpi stations. 


\section{References}

Budetta, G., Condarelli, D., Fytikas, M., Pascale, G., Pinna, E., and Rapolla, A., 1983. Prospezioni Giofisiche nelle isole di Santorini, Grecia. Rep. Inst. Geol. Miner. Explor., Athens, 1-38pp.

Chouet, B.A., 1985. Excitation of a buried magmatic pipe: A seismic source model for volcanic tremor, J. Geophys. Res., 90, 1881-1893.

Chouet, B.A., 1986. Dynamics for a fluid-driven crack in three dimensions by the finite difference method, J. Geophys. Res., 91, 967-992.

Chouet, B.A., 1988. Resonance of a fluid driven crack: radiation properties and implications for the source of long-period events and harmonic tremor, J. Geophys. Res., 93, 4375-4400.

Chouet, B.A., 1996a. Long-period volcano seismicity: its source and use in eruption forecasting, Nature, 380, 309-316.

Chouet, B.A., and Julian, B.R., 1985. Dynamic of an expanding fluid-filled crack, J. Geophys. Res., 90, 11187-11198.

Crosson, R.S., 1976. Crustal structure modeling of earthquake data; 1, Simultaneous least squares estimation of hypocenter and velocity parameters, J. Geophys. Res., 81, 3036-3046.

Delibassis, N., Chailas, S., Lagios, E., and Drakopoulos, J., 1989. Surveillance of Thera Volcano (Greece): Microseismological Monitoring, 3rd International Congress 'Thera and the Aegean World'. Santorini, 3-8 September 1989, vol. II, 199-206pp.

Delibassis, N., Sachpazi, M., Chailas, S., and Karantonis, G., 1993. Microearthquake activity of the Santorini Volcanic island during the period 1985-1989, Ann. Geol. de Pay Hellenique, $36,181-207$.

Dimitriadis, I.M., Panagiotopoulos, D.G., Papazachos, P.M., and Hatzidimitriou, E.E., Karagianni and Kane I, 2005. Recent seismic activity (1994-2002) of the Santorini volcano using data from local seismological network. The South Aegean Active Volcanic Arc. In M. Fytikas and G.E. Vougioukalakis (eds), Developments in Volcanology, vol.7. Elsevier B.V.

Druitt, T.H., Mellors, R.A., Pyle, D.M., and Sparks, R.S.J., 1989. Explosive mechanism on Santorini, Greece, Geophysical Magazine, 126, 95-126.

Druitt, T.H., Davies, M.S., Edwards, .L., Sparks, R.S.J., Mellors, R.M., Pyle, D.M., Lanphere, M., and Barreirio, B., 1999. The Santorini volcano, Geological Society Special Memoir, 19 Geological Society Pub House, London.

Dziak, R.P., and Fox, C.G., 2002. Evidence of harmonic tremor from a submarine volcano detected across the Pacific Ocean basin. J. Geophys. Res., 107 (B5), doi: $10.1029 / 2001 \mathrm{JB} 000177$.

Fytikas, M., Kolios, N., and Vougioukalakis, G., 1990. Post-Minoan Volcanic Activity of the Santorini Volcano. Volcanic hazard and risk, forecasting possibilities. In D.A. Hardy (ed.), Thera and the Aegean World III, 2. The Thera Foundation, London, 183-198pp.

Goldstein, P., Dodge, D., Firpo, M., and Ruppert, S., 1998. What's new in SAC2000? Enhanced processing and database access, Seismol. Res. Lett., 69, 202-205.

Goldstein, P., and Minner, L., 1996. SAC2000: seismic signal processing and analysis tools for the $21^{\text {st }}$ century, Seismol. Res. Lett., 67,39 .

Hurst, A.W., 1992. Stochastic simulation of volcanic tremor from Ruapehu, J. Volcanol. Geotherm. Res., 51, 185-198. 
Jousset, P., Neuberg, J., and Sturton, S., 2003. Modelling the time-dependent frequency content of the low-frequency volcanic earthquakes, J. Volcanol. Geotherm. Res., 128, 201-223.

Karagianni, E.E., Panagiotopoulos, D.G., Panza, G.F., Suhadolc, P., Papazachos, C.B., Papazachos, B.C., Kiratzi, A., Hatzfeld, D., Makropoulos, K., Priestley, K., and Vuan, A., 2002. Rayleigh wave group velocity tomography in the Aegean area, Tectonophysics, 358, 187-209.

Kassaras, I., 2002. Upper mantle structure of the Aegean region derived from the dispersion of seismic surface waves, PhD Thesis, University of Athens, Greece.

Kawakatsu, H., Kaneshima, S., Matsubayashi, H., Ohminato, T., Sudo, Y., Tsutsui, T., Uhira, K., Yamasato, H., and Legrand, D., 2000. Aso94: Aso seismic observation with broandband instruments, J. Volcanol. Geotherm. Res., 101, 129-154.

Kissling, E., Ellsworth, W.L., Eberhart-Phillips, D. \& Kradofler, D., 1994. Initial reference models in local earthquake tomography, J. Geoph. Res., 99, 19635-19646.

Kissling, E., Solarino, S., and Cattaneo, M., 1995. Improved seismic velocity reference model from local earthquake data in Northwestern Italy, Terra Nova, 7, 528-534.

Konstantinou, I., and Schlidwein, V., 2002. Nature, wavefield properties and source mechanism of volcanic tremor: a review, J. Volcanol. Geotherm. Res., 119, 161-187.

Latter, J., 1979. Volcanological observations at Tongarino national park. 2: Types and classification of volcanic earthquakes 1976-1978, Geophysics Division Report 150, Dept. Sci. Ind. Res.

Lee, W.H., and Lahr, J.E., 1975. HYPO71 a computer program for determining hypocenter magnitude and first motion pattern of local earthquakes, Geol. Survey Open-File Report, USA, 75-311.

Leet, R.C., 1988. Saturated and subcooled hydrothermal boiling in groundwater flow channels as a source of harmonic tremor, J. Geophys. Res., 93, 4835-4849.

McNutt, S.R., 1986. Observations and analysis of B-type earthquakes, explosions and volcanic tremor. At Pavlof Volcano, Alaska. Bull. Seismol. Soc. Am., 76, 153-175.

McNutt, S.R., 1996. Seismic monitoring and eruption forecasting of volcanoes: A review of the state-of-the-art and case histories. In Scarpa, Tilling (eds.), Monitoring and Mitigation of Volcanic Hazards, Springer, Berlin, 100-146pp.

McNutt, S.R., (2000). Volcanic seismicity. In: Sigurdsson H. (Ed.), Encyclopedia of volcanoes, Academic Press San Diego, 1015-1033.

Makropoulos, K., Kouskouna, V., Karnassopoulou, A., Dando, P., and Varnavas, S.P., 1998. Seismicity in the Aegean hydrothermal system in relation to biogeochemical parameters, submitted to J. Physics and Chemistry of the Earth.

Mascle, J., and Martin, L., 1990. Shallow structure and recent evolution of the Aegean sea: A synthesis based on continuous reflection profiles, Mar. Geol., 94, 271-299.

McKenzie, D.P., 1978. Active tectonics of the Alpine Himalayan Belt: The Aegean Sea and surrounding regions, Geophys. J.R. Astron. Soc., 55, 217-254.

Minakami, T., 1960. Fundamental research for predicting volcanic eruptions (Part 1), Bull. Earthq. Res. Inst. Univ. Tokyo, 38, 497-544.

Minakami, T., 1974. Seismology of volcanoes in Japan. In Civetta et al. (eds) Physical Volcanology Developments in Solid Earth Geophysics vol 6. Elsevier Amsterdam 1-27pp. 
Neuberg, J., Luckett, R., Baptie, B., and Olsen, K., 2000. Models of tremor and low-frequency earthquake swarms on Montserrat, J. Volcanol. Geotherm. Res., 101, 83-104.

Papanikolaou, D., Lekkas, E., Syskakis, D., and Adamopoulou, E., 1993, Correlation on neotectonic structures with the geodynamic activity in Milos during the earthquakes of March 1992, Bull. Geol. Soc. Greece, XXVIII/3, 413-428.

Papazachos, B.C., 1989. Long and short term prediction of the volcanic eruption in Santorini. In Proceedings of 3rd International Congress 'Thera and the Aegean World III', Volume 2, September 4-8 1989, Santorini, Greece, 125-129pp.

Papazachos, B.C., Kiratzi, A.A., and Papadimitriou, E.E., 1991. Regional focal mechanisms for earthquakes in the Aegean area, Pure Appl. Geophys. 136, 405-420.

Papazachos, B.C., Mountrakis, D.M., Papazachos, C.B., Tranos, M.D., Karakaisis, G.F., and Savaidis, A.S., 2001. The fault which has caused the known major earthquakes in Greece and sourrounding region between the 5th century $\mathrm{BC}$ and today. Proceedings of $2 n d$ National Conference Anti-Seismic Engineering and Technical Seismology, November 2830, 2001, Thessaloniki, Greece, 17-26pp.

Papazachos, B.C., and Panagiotopoulos, D., G., 1993. Normal faults associated with volcanic activity and deep rupture zones in the southern Aegean volcanic arc, Tectonophysics, 220, 301-308.

Pavlides, S.B., and Valcaniotis, S., 2003. Tectonic regime of Santorini-Amorgos area, Proceedings of International Conference "The South Aegean Active Volcanic Arc: Present Knowledge and Future Perspectives”, September 17-20 2003, Milos Island, Greece. Book of abstracts, 76p.

Perissoratis, C., 1996. The Santorini volcanic complex and its relation to the stratigraphy and structure of the Aegean arc, Greee, Marine Geology, 128, 37-58.

Schlidwein, V., Wasserman, J., and Scherbaum, F., 1995. Spectral analysis of harmonic tremor signals from Mt. Semeru, Indonesia, Geophys. Res. Lett., 22, 1685-1688.

Seidl, D., Schick, R., and Riuscetti, M., 1981. Volcanic tremors at Etna: A model for hydraulic origin, J. Volcanol. Geotherm. Res., 44, 43-56.

Seidl, D., Kirbani, S.B., and Brustle, W., 1990. Maximum entropy spectral analysis of volcanic tremor using data from Etna (Sicily) and Merapi (central Java), Bull. Volcanol., 52, 460474.

Sherburn, S., Scott, B.J., Nishi, Y., and Suguhara, M., 1998. Seismicity at White Island volcano, New Zealand: a revised classification and inferences about source mechanism, J. Volcanol. Geotherm. Res., 83, 287-312.

Shirokova, E., 1972. Stress pattern and probable motion in the earthquake foci of the Asia Mediterranean seismic belt. In L.M. Balakina et al. (eds), Elastic Strain Field of the Earth and Mechanisms of Earthquake Sources, Nauka, Moscow, p.8.

Talandier, J., and Okal, E.A., 1996. Monochromatic T waves from underwater in the Pacific Ocean: ringing witnesses to geyser processes? Bulletin of the Seismological Society of America, 86 (5), ringing 1529-1544. 